BBA 71502

\title{
MODULATION OF GLUCOSE TRANSPORT IN HUMAN RED BLOOD CELLS BY ATP
}

\author{
JOHN A. JACQUEZ \\ Department of Physiology, The University of Michigan, Ann Arbor, MI 48109 (U.S.A.)
}

(Received August 12th, 1982)

Key words: Glucose transport; ATP activation; (Erythrocyte)

Depletion of energy stores of human red cells decreases the maximum transport capacity, $J_{m}$, for glucose transport to a value one-third or less of that found in red cells from freshly drawn blood. There is no change in $K_{m}$. Hemolysis and resealing of red cells with ATP or ADP reverses the decrease in $J_{m}$. The maximum effect occurs at concentrations of ATP in the normal range for red cells, however, there is little effect from ADP concentrations in its normal range in freshly drawn red cells. Hemolysis and resealing with ATP gives an increase in $J_{m}$ and an increase in differential labeling by photolytic labeling with tritiated cytochalasin $B$. Most of the activation is lost after a second hemolysis-reseal without ATP but about $25 \%$ of the activation remains.

\section{Introduction}

The activity of the facilitated diffusion system for glucose is modulated by a number of agencies in many cell types. The stimulation by insulin in muscle and fat cells plays an important role in the regulation of plasma glucose levels and in the control of metabolism [1]. In muscle, hypoxia and contraction have effects similar to those of insulin. The system in the human red blood cell has a number of unique characteristics. It is a system of high capacity and is asymmetric. The latter property has been explained by some as being due to the presence of two carriers with different affinities [2-5]. However, it is not influenced by insulin or anoxia and is often viewed as a basic system stripped of the control features found in other cells. Elbrink and Bihler [6] classified it as a nonregulated system. I show here that its $J_{\mathrm{m}}$ depends on ATP levels.

The work reported here was started to examine the effect of intracellular calcium levels on glucose transport. A decrease in glucose transport was found in cells treated with A23187 in the presence of calcium. As will be seen this is due to a change in metabolic state and is not due to any direct effect of increased calcium levels in the red blood cell. Some of the results of this study have been reported in abstract form [7].

\section{Methods and Materials}

Preparation of red blood cells. Blood or packed red blood cells were obtained from the University of Michigan Hospital Blood Bank. This blood is stored in CPDAl (citrate, phosphate, dextrose and adenine) and has an expiration date 35 days after drawing. The evening before an experiment the red blood cells were washed twice by suspending them in isotonic saline to a volume 5-6-fold that of the packed cell volume and were centrifuged for 7-8 $\mathrm{min}$ in an International centrifuge, size 2, model $\mathrm{K}$ at $1000 \times \mathrm{g}$. The buffy coat was siphoned off with the supernatant fluid. This was repeated three times but with resuspension to 10 -fold the packed cell volume and incubation for 3-6 min at $37^{\circ} \mathrm{C}$ before centrifugation. The cells were finally suspended in a balanced salt solution (BSS) at a 
hematocrit of 0.2 and were kept in a cold room at $2-4^{\circ} \mathrm{C}$. For some studies the final incubation-wash and adjustment of cell concentration was done on the morning of the experiment.

The washes were designed to wash out residual glucose so that the uptakes would not be affected by exchange stimulation. Batt and Schachter [8] reported that two 5 -min washes at $37^{\circ} \mathrm{C}$ with 9 volumes of saline reduced intracellular glucose levels from 14 to $0.1 \mathrm{mM}$.

Media. The balanced salt solution (BSS) was made up to contain $60 \mathrm{mM} \mathrm{NaCl}, 75 \mathrm{mM} \mathrm{KCl}, 1$ $\mathrm{mM} \mathrm{MgCl} 2$ and $10 \mathrm{mM}$ Tris and was titrated to $\mathrm{pH} 7.4$ with $\mathrm{HCl}$. Calcium was added as $\mathrm{CaCl}_{2}$ to obtain levels $10^{-5} \mathrm{M}$ or higher; lower concentrations were set with EGTA-calcium buffers with EGTA at 0.5 or $1 \mathrm{mM}$.

The high potassium medium was used to prevent change in cell volume in A23187-treated cells. Some experiments were run in high sodium balanced salt solution with no difference in results, but the cells shrank in volume due to increased loss of potassium in calcium containing media, the Gardos effect [9]. With the high potassium medium there was no significant decrease in hematocrit of A23187-treated suspensions.

The stopper solution used to stop glucose uptake contained $1.25 \mathrm{mM} \mathrm{KI}, 1 \mu \mathrm{M} \mathrm{HgCl}_{2}$ and 50 $\mu \mathrm{M}$ phloretin in balanced salt solution [10].

Uptakes. Five $\mathrm{ml}$ of a suspension of the washed red blood cells in a $125 \mathrm{ml}$ erlenmeyer was incubated in a rocker-type water bath in a cold room. In the early experiments uptakes were done at the cold room temperature, $1-4^{\circ} \mathrm{C}$. But in most of the experiments the water bath was set at $5^{\circ} \mathrm{C}$ and the temperature fell in the range $4.4-5.6^{\circ} \mathrm{C}$. To start the uptakes $5 \mathrm{ml}$ balanced salt solution containing $1 \mathrm{mM}$ D-glucose with uniformly labeled $\mathrm{D}-\left[{ }^{14} \mathrm{C}\right]$ glucose as tracer and $1 \mathrm{mM} \mathrm{L}$-glucose with tritiated L-glucose as tracer was added. One $\mathrm{ml}$ samples were taken at 15 -s intervals out to $1.5 \mathrm{~min}$ and injected into $10 \mathrm{ml}$ of cold stopper solution in $15 \mathrm{ml}$ plastic centrifuge tubes. The tubes were spun in Precision Vari-Hi-Speed Centricone clinical centrifuges at $4500 \mathrm{rpm}$ for $6 \mathrm{~min}$. The supernatant solutions were saved for counting; the pellets were washed with another $10 \mathrm{ml}$ of stopper solution. The pellets were extracted by resuspending each with $0.5 \mathrm{ml}$ isotonic $\mathrm{NaCl}$, adding $1 \mathrm{ml}$
$8 \%$ trichloroacetic acid and pouring into a $5 \mathrm{ml}$ volumetric. The tube was washed out with $3 \mathrm{ml}$ of $2 \%$ trichloroacetic acid in 0.25 isotonic $\mathrm{NaCl}$, and the wash added to the volumetric. After dilution to the mark the volumetric was emptied into a graduated centrifuge tube and centrifuged in the International centrifuge. The precipitate volume was measured, and $0.5 \mathrm{ml}$ of the supernatant solution was added to $10 \mathrm{ml}$ toluene scintillator fluid and $5 \mathrm{ml}$ absolute ethanol for counting.

At low rates, uptakes were linear out to $1.5 \mathrm{~min}$, and the six time points could be fitted with a straight line with a coefficient of determination which was rarely less than 0.99 . For higher uptake rates, the first three time points appeared to be linear, but there was a small curvature, concave towards the time axis, at the later points. These could be fitted with a quadratic with goodness of fit comparable to that of the linear fits. In both cases the initial slope was taken to calculate initial uptake rates.

Studies on resealed red blood cells. To incorporate compounds into the intracellular phase, red blood cells were hemolyzed and resealed using a modification of methods described by Schwoch and Passow [11], Johnson [12], and Johnson and Kirkwood [13]. For these experiments the red blood cells were suspended in balanced salt solution at a hematocrit of 0.5 . The hemolysis solution contained $4 \mathrm{mM} \mathrm{MgCl}_{2}, 4.5 \mathrm{mM}$ Tris, $0.5 \mathrm{mM}$ EGTA, $1 \mathrm{mM} \mathrm{KH} \mathrm{PO}_{4}$ and $10^{-5} \mathrm{M} \mathrm{CaCl}_{2}$. Compounds to be incorporated in the intracellular phase were dissolved in the hemolysis solution which was then titrated to $\mathrm{pH}$ 7.1. The cell suspension and hemolysis solution were kept on ice in the cold room. Three $\mathrm{ml}$ of cold cell suspension were added to 30 $\mathrm{ml}$ hemolysis solution with stirring; after $5 \mathrm{~min} 4.5$ $\mathrm{ml}$ of $1.254 \mathrm{M} \mathrm{KCl}$ was added. The suspension was allowed to sit on the ice for $5 \mathrm{~min}$ and was then incubated for $1 \mathrm{~h}$ in a rocker-type water bath at $37^{\circ} \mathrm{C}$. After the incubation the cells were spun down in $50 \mathrm{ml}$ centrifuge tubes at $17000 \mathrm{rpm}$ for 7-10 $\mathrm{min}$ in a Sorvall SS-3. In this first centrifugation there was usually a small hard pellet of darker cells on the wall in the center of the larger fluffy pellet of resealed cells. This small pellet was firmly attached to the wall of the centrifuge tube, so it was easy to resuspend the larger fluffy pellet and pour it off, leaving the small hard pellet behind. 
The resealed cells were washed once with balanced salt solution and resuspended to $5 \mathrm{ml}$ in balanced salt solution and transferred to a $125 \mathrm{ml}$ erlenmeyer flask for the glucose uptake measurements. The latter were carried out as for intact red blood cells except that the samples were delivered into $20 \mathrm{ml}$ stopper solution and the cells were packed in the Sorvall.

Polyacrylamide gel electrophoresis. $0.5-1 \mathrm{mg}$ of ghost protein was solubilized in $0.2-0.25 \mathrm{ml}$ of a solution containing $10 \%$ glycerol $(\mathrm{v} / \mathrm{v}), 3 \%$ SDS, $1 \%$ mercaptoethanol $(\mathrm{v} / \mathrm{v})$ in $10 \mathrm{mM}$ phosphate buffer, pH 7.1.

Five percent gels, $10-11 \mathrm{~cm}$ long, were cast in tubes of $9 \mathrm{~mm}$ inner diameter. The electrophoresis buffer and method have been described [14]. The entire sample of $0.5-1 \mathrm{mg}$ protein was run on a gel.

Counting. All samples were counted on a Tracor Analytic Model 6892 liquid scintillation counter in $10 \mathrm{ml}$ of a toluene-based scintillator, Liquiflor ${ }^{\circledR Q}$, with $5 \mathrm{ml}$ absolute ethanol added. In almost all experiments simultaneous uptakes of D- $\left[{ }^{14} \mathrm{C}\right]$-glucose and $\mathrm{L}_{-}\left[{ }^{3} \mathrm{H}\right]$ glucose were followed so double label counting methods were used.

Materials. D- $\left[{ }^{14} \mathrm{C}\right]$-Glucose was uniformly labeled, $3 \mathrm{mCi} / \mathrm{mmol}$ from Amersham. $\mathrm{L}-\left[{ }^{3 \mathrm{H}}\right] \mathrm{Glu}-$ cose was $\mathrm{L}-\left[1-{ }^{3} \mathrm{H}\right] \mathrm{glucose}, 10.7 \mathrm{Ci} / \mathrm{mmol}$ from New England Nuclear.

All nonradioactive compounds were the best grade available. Most were from Sigma; A23187 was from CalBiochem.

Calculation of free calcium concentrations. The free calcium concentrations for Ca-EGTA buffers were calculated for $\mathrm{pH} 7.4$ at $25^{\circ} \mathrm{C}$ for solutions of ionic strength 0.1 using association constants chosen from data reported by Martell and Smith [15], Sillen and Martell [16] and Perrin [17]. The values used for the logarithms of the association constants for EGTA were, $K_{1} 9.44, K_{2} 8.89, K_{3} 2.73$, $K_{4} 2.08, K_{\mathrm{Ca}} 10.93, K_{\mathrm{CaH}} 3.80, K_{\mathrm{Mg}} 5.24, K_{\mathrm{MgH}}$ 7.61 .

Calculation of fluxes. Because thi supernatants and the pellet extracts usually differed a little in quench, their $\mathrm{cpm}$ were first corrected to the same quench, i.e. the same external standards ratio, with a curve prepared from a set of quenched standards.

For the calculations define the following: $a_{1}$, initial slope of curve of uptake for $0.5 \mathrm{ml}$ of extract of pellets from erythrocytes of one $\mathrm{ml}$ of suspension; $2 a_{1}$ has units $\mathrm{cpm} / \mathrm{ml}$ per min.

$v$, volume of pellet extract; $0.5 \mathrm{ml}$ was counted; $v$ fell in the range 4.92-5.0.

$K$, conversion factor from radioactivity to amount, $\mathrm{cpm} / \mu \mathrm{mol}$.

$D$, dilution of the supernatant of the $1 \mathrm{ml}$ of suspension after addition to $V \mathrm{ml}$ of stopper solution. Of the packed cell volume (PCV) sorbitol space estimates gave $6 \%$ for the extracellular fluid for erythrocytes; thus $D=(V+1-0.94 \mathrm{PCV}) /(1$ $-0.94 \mathrm{PCV}) . V$ was $10 \mathrm{ml}$ for intact erythrocytes. For hemolyzed-resealed cells, sorbitol space was $10 \%$ of the PCV and $V$ was $20 \mathrm{ml} .0 .5 \mathrm{ml}$ of the stopper solution was counted. Hematocrits were 0.09-0.1 for erythrocytes, 0.15 for resealed cells. Inadvertently 0.94 was used in the first calculations for resealed ghosts as well as for erythrocytes but it turned out that this made less than 1\% difference in the results.

$S$, cpm in $0.5 \mathrm{ml}$ of the stopper solution supernatant. $2 S$ has units $\mathrm{cpm} / \mathrm{ml}$.

The initial uptake rate and the extracellular concentrations are given by Eqns. 1 and 2, respectively.

$R=\frac{2 a_{1} \cdot v}{K} \mu \mathrm{mol} / \mathrm{min}$

$c=\frac{2 S \cdot D}{K} \mu \mathrm{mol} / \mathrm{ml}$

Except for studies of concentration dependence of initial flux, uptakes were done at $c=0.5 \mathrm{mM}$ which is approximately the $K_{\mathrm{m}}$ at $5^{\circ} \mathrm{C}$. For comparison of uptakes the flux coefficient was calculated as the initial uptake rate per $\mathrm{ml}$ of packed cells divided by the extracellular concentration, Eqn. 3.

$\frac{J}{c}=\frac{1}{\mathrm{PCV}} \frac{R}{c}=\frac{1}{\mathrm{PCV}} \frac{a_{1} \cdot v}{S \cdot D} \min ^{-1}$

\section{Results}

I. Results with intact erythrocytes

L-Glucose controls

The initial influx of L-glucose was measured 
simultaneously with that for D-glucose. The erythrocyte uptake curves were always flat; the uptake of L-glucose was not significantly different from zero.

\section{Effect of depletion}

In the studies that initiated this work it was found that incubation of washed erythrocytes with A23187 at $37^{\circ} \mathrm{C}$ in the presence of calcium gave an inhibition of initial influx of glucose. At A23187 levels of $0.02 \mathrm{mg} / \mathrm{ml}$ it took approx. $1 \mathrm{~h}$ for the full effect to develop; for incubation times of $1 \mathrm{~h}$ essentially the same inhibition was obtained for A23187 concentrations of $4 \cdot 10^{-3}$ to $10^{-1} \mathrm{mg} / \mathrm{ml}$, the effect decreasing for concentrations below $10^{-3}$ $\mathrm{mg} / \mathrm{ml}$. Calcium at levels of about $10^{-6} \mathrm{M}$ or higher had to be present in the medium and the effect decreased as calcium levels decreased to $10^{-8} \mathrm{M}$ and no effect was detected for calculated free calcium levels at or below $10^{-9} \mathrm{M}$. No inhibition occurred for incubation with $\mathrm{A} 23187$ at $2{ }^{\circ} \mathrm{C}$ for up to $4 \mathrm{~h}$.

Although at first I thought I had found a calcium effect, as will be seen from the results that

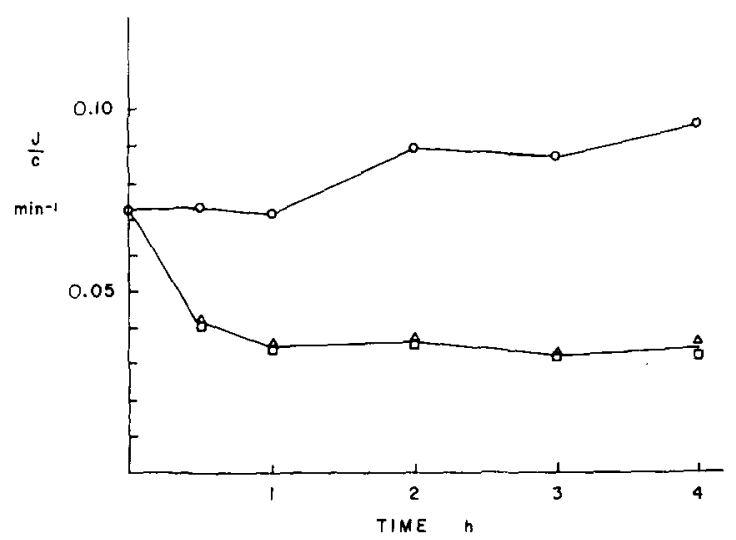

Fig. 1. Time course of development of effect of A23187 and of iodoacetamide plus inosine on glucose zero-trans initial flux coefficient $(J / C)$. For this experiment a high-sodium balanced salt solution containing $2 \cdot 10^{-5} \mathrm{M}$ calcium was used $\square \longrightarrow \square, 0.1 \mathrm{ml}$ of $1 \mathrm{mg} / \mathrm{ml} \mathrm{A23187} \mathrm{in} \mathrm{DMSO} \mathrm{was} \mathrm{added} \mathrm{to}$ $10 \mathrm{ml}$ of suspension to give $0.01 \mathrm{mg} / \mathrm{ml} . \Delta-\Delta$, iodoacetamide and inosine were added to the suspension to give final concentrations of $6 \mathrm{mM}$ and $10 \mathrm{mM}$, respectively. $\mathrm{O}-\mathrm{O}$. DMSO control. Erythrocytes were from 50-day-stored bank blood. The suspensions were incubated at $37^{\circ} \mathrm{C}$ with gentle rocking for the times indicated and were then chilled, taken to a cold room and uptakes were measured at $2.5-3.5^{\circ} \mathrm{C}$. follow, the effect is due to a metabolic depletion. A similar effect was obtained by incubating the cells with $6 \mathrm{mM}$ iodoacetamide and $10 \mathrm{mM}$ inosine to deplete them [8]. Fig. 1 shows the results of incubation with A23187 and with iodoacetamide plus inosine using 50-day-stored blood from the blood bank. Two points need to be made about this graph. Firstly, it was not unusual to find a small increase in flux coefficient with time of incubation in the controls but it did not always occur (see for example Fig. 3). The effects of iodoacetamide plus inosine were the same as those of A23187 for this blood but in two other tests the inhibition given by iodoacetate plus inosine was slightly larger. Finally the inhibition after $1 \mathrm{~h}$ incubation with iodoacetamide occurred even if free calcium was set below $10^{-9} \mathrm{M}$ with EGTA buffer.

\section{Reversibility of inhibition}

After development of the inhibition with A23187, lowering the free calcium to well below $10^{-9} \mathrm{M}$ by addition of EGTA did not reverse the inhibition, Fig. 2. However, repletion by incubation with pyruvate, inosine, adenine and glucose followed by washing to remove glucose did reverse the inhibition, as seen in Fig. 3. Fig. 3 also shows the inhibition obtained with iodoacetamide and

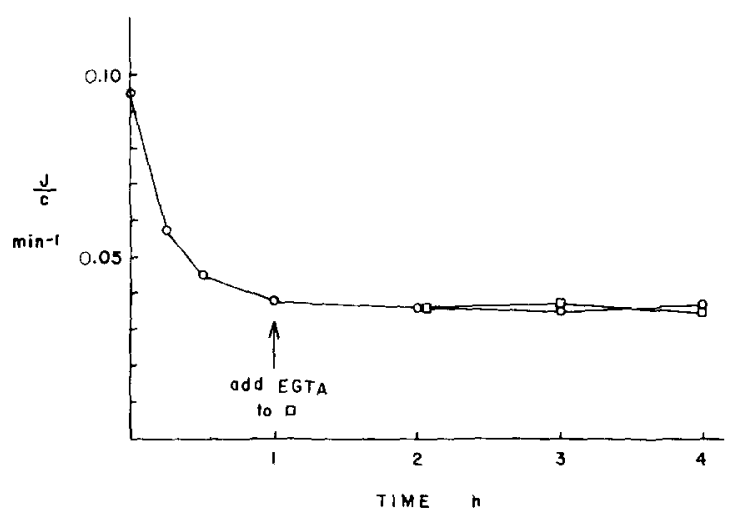

Fig. 2. Non-reversibility of the ionophore effect by removal of free calcium. Calcium concentration was $2 \cdot 10^{-5} \mathrm{M}$. At $1 \mathrm{~h}$, arrow, EGTA to a final concentration of $2 \mathrm{mM}$ was added ( $\square-\square$ ), sufficient to lower the free calcium to below $10^{-9} \mathrm{M} . \mathrm{O}-\mathrm{O}$, Control. A high-sodium balanced salt solution was used in this experiment and the uptake assay was run at $3^{\circ} \mathrm{C}$. Bank blood, 42-days stored. Plot of flux coefficient $(\mathrm{J} / \mathrm{c})$ against time. 


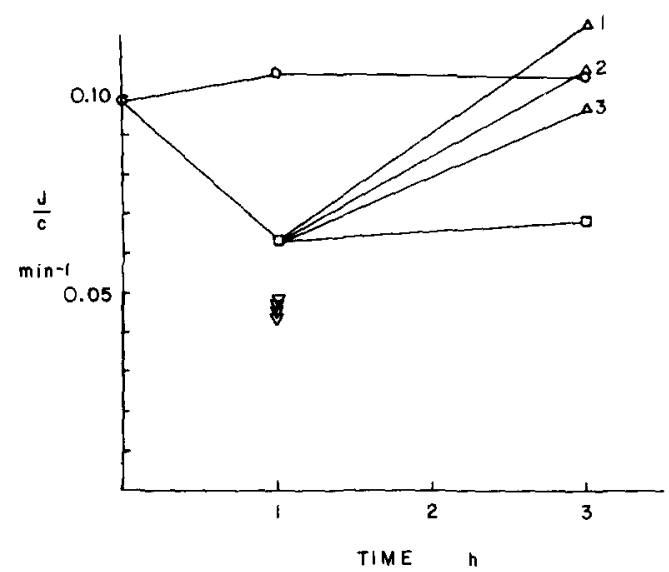

Fig. 3. Repletion of A23187-treated cells by incubation with pyruvate, ionosine, glucose and adenine (PIGA). Suspensions were incubated at $37^{\circ} \mathrm{C}$ for the times shown. A high-potassium balanced salt solution was used containing $2 \cdot 10^{-5} \mathrm{M}$ calcium. $\mathrm{O}-\mathrm{O}$, controls. $\square-\square$ and $\Delta-\Delta$, treated with $0.01 \mathrm{mg} / \mathrm{ml} \mathrm{A23187}$. After $1 \mathrm{~h}$ of incubation $2 \mathrm{mM}$ EGTA, 5 $\mathrm{mM}$ pyruvate, $5 \mathrm{mM}$ inosine, $10 \mathrm{mM}$-glucose and $5 \mathrm{mM}$ adenine were added to three A23187-treated flasks: $\triangle 1$, PIGA; $\triangle 2$, PIGA plus $2 \mathrm{mM}$ cysteine; $\triangle 3$, PIGA plus $1 \mathrm{mM}$ glycine, 1 $\mathrm{mM} \mathrm{L}$-glutamine and $1 \mathrm{mM}$ cysteine. After two more hours of incubation all samples were subjected to the incubation-wash procedure and were assayed for glucose uptake at $3^{\circ} \mathrm{C}$. Also shown are inhibitions obtained with iodoacetamide plus inosine $(\nabla)$ : two of these were for $\left[\mathrm{Ca}^{2+}\right]=2 \cdot 10^{-5} \mathrm{M}$, two for $\left[\mathrm{Ca}^{2+}\right]$ $=4 \cdot 10^{-10} \mathrm{M}$. Bank blood 51 days old.

inosine with this blood. Repletion by this method was not done with cells treated with iodoacetamide plus inosine. The resealing studies are more specific and in those, resealing with $2 \mathrm{mM}$ ATP returned the flux coefficient to levels seen with red blood cells from freshly drawn blood, for cells treated with A23187 or with iodoacetamide plus inosine.

Is the inhibitory effect an effect on $J_{m}$ or $K_{m}$ ?

Fig. 4 gives a Hofstee plot of a concentration dependence study on red cells from a 28-day bank blood. The A23187-treated cells show a decrease in $J_{\mathrm{m}}$ but no change in $K_{\mathrm{m}}$. Direct fit of the Hofstee plot with unweighted linear regression gives $J_{\mathrm{m}}=0.145, K_{\mathrm{m}}=0.49$ for the controls and $J_{\mathrm{m}}=0.095, K_{\mathrm{m}}=0.48$ for the cells treated with A23187. Direct fit of the Michaelis-Menten equation by weighted nonlinear least squares using the inverse square of the predicted value, $1 /(J)^{2}$, for

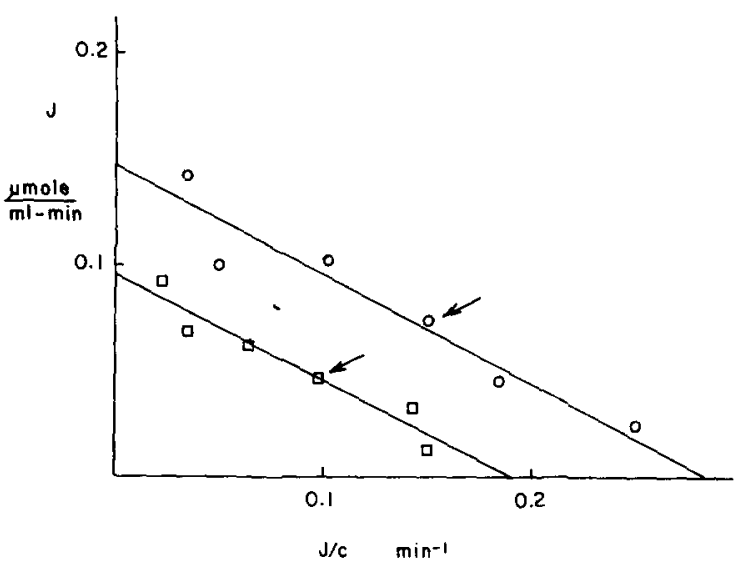

Fig. 4. Hofstee plot from a study of dependence of flux on glucose concentration. $\mathrm{O}-\mathrm{O}$, controls, incubated $1 \mathrm{~h}$ with DMSO. $\square-\square$, A23187-treated cells, incubated ith with $0.011 \mathrm{mg} / \mathrm{ml} \mathrm{A23187;0.057} \mathrm{ml}$ of DMSO solution added to $5 \mathrm{ml}$ cell suspension. Assays for glucose uptake at $5^{\circ} \mathrm{C}$. Bank blood, 28 days old. The fitted lines are calculated from a weighted nonlinear least-squares fit of the Michaelis-Menten equation.

weight at each point gave $J_{\mathrm{m}}=0.147, K_{\mathrm{m}}=0.51$ and $J_{m}=0.095, K_{m}=0.50$. The lines in Fig. 4 are calculated with the parameters from the fit of the Michaelis-Menten equation. The arrows on the figure point to the data for $c=0.5$ and 0.49 for controls and A23187, respectively.

\section{Results on fresh and stored bank blood}

The results suggest that the inhibition of glucose transport is due to depletion of energy stores of the red blood cells. Since this occurs normally on storage of bank blood one would expect to find higher flux coefficients in freshly drawn blood. A separate study on changes in bank blood is being prepared for publication elsewhere. Here I summarize a study on my own blood; the flux coefficient after drawing and through the first five days was $0.33-0.34$ and fell over the next three weeks to 0.2 where it stayed up to 6 weeks after drawing. Treatment with A23187 for $1 \mathrm{~h}$ lowered the flux coefficient to values in the range $0.075-0.13$. Professor W. Stein of the Weizman Institute has also found a decrease in exchange flux of glucose in stored red cells (personal communication). 


\section{Results with hemolyzed-resealed cells}

\section{L-Glucose controls}

For cells subjected to one hemolysis and reseal the L-glucose uptake curve had a small slope corresponding to $1-3 \%$ of that of the D-glucose uptake. The correction was so small it had no effect on the results and was not used. The correction was larger for cells subjected to two hemolysis and reseal cycles. For such preparations there was a measurable washout of D-glucose in the washing of the cells and this was corrected for by counting the second wash from the uptake method, calculating the loss from the slope of the wash counts in D-glucose, and adding the washed-out material back to the pellet amount; this correction was $10-18 \%$ of the total. The second wash was not always counted so the correction could not always be made.

\section{TABLE I}

\section{RESEAL EXPERIMENTS THAT GAVE NO EFFECTS OR} SMALL EFFECTS

All uptakes fell near the values for cells treated with A23187 and less than controls treated with DMSO; flux coefficients for A23187-treated cells were 66-99\% of those for controls, mean $80.4 \%$, standard deviation $12.6 \%$. Note that for the old bank bloods used glucose uptake is already considerably less than for cells from freshly drawn blood. G6P, glucose 6-phosphate; DPG, 2,3-diphosphoglycerate.

\begin{tabular}{lcc}
\hline Intermediate & $\begin{array}{l}\text { Concentration } \\
\text { tested }(\mu \mathrm{M})\end{array}$ & $\begin{array}{l}\text { Average } \\
\text { normal } \\
\text { values }(\mu \mathrm{M}) \\
{[18]}\end{array}$ \\
\hline Glucose 6-phosphate & 63,89 & 43 \\
Fructose 6-phosphate & 46 & 20 \\
Fructose 1,6-diphosphate & 10 & 4.1 \\
2,3-Diphosphoglycerate & $1250 ; 2000$ & 7611 \\
2-Phosphoglycerate & 32 & 14 \\
3-Phosphoglycerate & 120 & 98 \\
AMP & 87 & 38 \\
ADP & 201 & 120 \\
Cyclic AMP & 63 & - \\
Mixtures (concentrations in $\mu$ M) & \\
NADH (64)+NADPH (62) & \\
cAMP (63)+G6P (82)+DPG (73) & \\
ATP (63)+ADP (72)+AMP (69)+GSH (65) \\
NADH (72)+NADPH (62)+cAMP (71)+G6P (89) \\
$\quad$ + DPG (59)
\end{tabular}

Reseal with metabolic intermediates

In the experiments with resealed cells, the erythrocytes were incubated with $0.01-0.02 \mathrm{mg} / \mathrm{ml}$ A23187 for $1 \mathrm{~h}$ at $37^{\circ} \mathrm{C}$ in presence of calcium, were centrifuged and resuspended to a hematocrit of 0.5 , and were then subjected to the hemolysisreseal technique. The concentrations of intermediates given in the text and tables are the calculated concentrations at the start of the resealing incubation at $37^{\circ} \mathrm{C}$. Table I gives the intermediates and the concentrations tested which gave negative results or at the most small effects. By the latter I mean that the flux coefficients fell between those for A23187-treated cells and those for DMSO controls. However, when ATP was tested at 1.62 $\mathrm{mM}$ the flux coefficient was 3.6-times that of the A23187-treated cells. Note that the concentration of ATP in fresh erythrocytes is $2.24 \pm 0.27 \mathrm{mM}$ [18]. Table II gives results with adenine, adenosine, AMP, ADP and ATP, all at $1.61 \mathrm{mM}$; both ADP and ATP give comparable activation of glucose transport at the same concentration, a concentration below normal for ATP but many fold normal for ADP.

Activation of glucose transport by $A T P$ and $A D P$

Table III summarizes the activations obtained at calculated concentrations above $1 \mathrm{mM}$ from a variety of experiments with many different bank bloods. There is no question of the statistical significance of the effect; the results are significant by the simplest sign test. It should be noted that

TABLE II

EFFECT OF RESEALING WITH ADENINE, ADENOSINE AND ADENINE NUCLEOTIDES ON GLUCOSE TRANSPORT

Cells were incubated with $\mathrm{A} 23187$ for $1 \mathrm{~h}$ at $37^{\circ} \mathrm{C}$, then resealed with the indicated compound at $1.61 \mathrm{mM}$.

\begin{tabular}{ll}
\hline Compound & $\begin{array}{l}J / c \\
\left(\mathrm{~min}^{-1}\right)\end{array}$ \\
\hline Control & 0.056 \\
ATP & 0.176 \\
ADP & 0.170 \\
AMP & 0.054 \\
Adenosine & 0.057 \\
Adenine & 0.048 \\
\hline
\end{tabular}


TABLE III

RESULTS OF RESEAL STUDIES WITH ATP OR ADP

Cells incubated $1 \mathrm{~h}$ at $37^{\circ} \mathrm{C}$ with A23187 added in DMSO or DMSO except for last entry of $6 / 18$ in which cells were treated with iodoacetamide plus inosine instead of A23187.

\begin{tabular}{|c|c|c|c|c|c|c|c|}
\hline \multirow[t]{3}{*}{ Expt. } & \multirow{3}{*}{$\begin{array}{l}\text { Concn. } \\
\text { ATP or } \\
\text { ADP } \\
(\mathrm{mM})\end{array}$} & \multicolumn{6}{|c|}{$J / c\left(\min ^{-1}\right)$} \\
\hline & & \multicolumn{2}{|c|}{ Reseal, no ATP or ADP } & \multicolumn{2}{|c|}{ Reseal, ATP } & \multicolumn{2}{|c|}{ Reseal, ADP } \\
\hline & & DMSO & A231187 & DMSO & A23187 & DMSO & A23187 \\
\hline $10 / 20 / 81$ & 1.62 & 0.068 & 0.045 & - & 0.162 & - & - \\
\hline $11 / 5 / 81$ & 1.61 & 0.075 & 0.050 & - & 0.190 & - & - \\
\hline $11 / 24 / 81$ & 1.61 & 0.084 & 0.062 & - & - & - & 0.209 \\
\hline $12 / 10 / 81$ & 1.61 & - & 0.056 & - & 0.175 & - & 0.170 \\
\hline $12 / 17 / 81$ & 1.62 & 0.067 & 0.053 & - & - & 0.173 & 0.199 \\
\hline $12 / 27 / 81$ & 1.60 & - & $0.067,0.052$ & - & - & - & $0.129,0.126$ \\
\hline \multirow[t]{3}{*}{$2 / 4 / 82$} & 1.39 & - & 0.098 & - & - & - & 0.247 \\
\hline & 2.48 & - & 0.098 & - & - & - & 0.309 \\
\hline & 3.97 & - & 0.098 & - & - & - & 0.292 \\
\hline \multirow[t]{2}{*}{$3 / 12 / 82$} & 2.40 & - & 0.049 & - & 0.131 & - & 0.128 \\
\hline & $2.40^{a}$ & - & 0.051 & - & $0.167^{\mathrm{b}}$ & - & $0.154^{b}$ \\
\hline $3 / 25 / 82$ & $2.01^{\mathrm{a}}$ & - & 0.041 & - & $0.225^{b}$ & - & $0.178^{b}$ \\
\hline \multirow[t]{2}{*}{$4 / 29 / 82$} & 2.01 & - & 0.127 & - & 0.239 & - & - \\
\hline & $2.01^{\mathrm{a}}$ & - & 0.093 & - & 0.303 & - & - \\
\hline \multirow[t]{3}{*}{$5 / 25 / 82$} & 1.39 & - & 0.072 & - & 0.154 & - & - \\
\hline & 2.48 & - & 0.072 & - & 0.181 & - & - \\
\hline & 3.98 & - & 0.072 & - & 0.171 & - & - \\
\hline $6 / 15 / 82$ & $2.01^{\mathrm{a}}$ & - & $0.089,0.128$ & - & $0.293,0.311$ & - & - \\
\hline \multirow[t]{2}{*}{$6 / 18 / 82$} & 2.03 & 0.116 & 0.082 & 0.248 & 0.292 & - & - \\
\hline & $2.03^{c}$ & - & $(0.120,0.122)$ & - & $(0.282,0.289)$ & - & - \\
\hline
\end{tabular}

a Cells subjected to two cycles of hemolysis and reseal with ATP or ADP present in second reseal.

b Data not corrected for leak in second wash after two hemolysis and reseal cycles.

c Cells treated with iodoacetamide plus inosine instead of A23187.

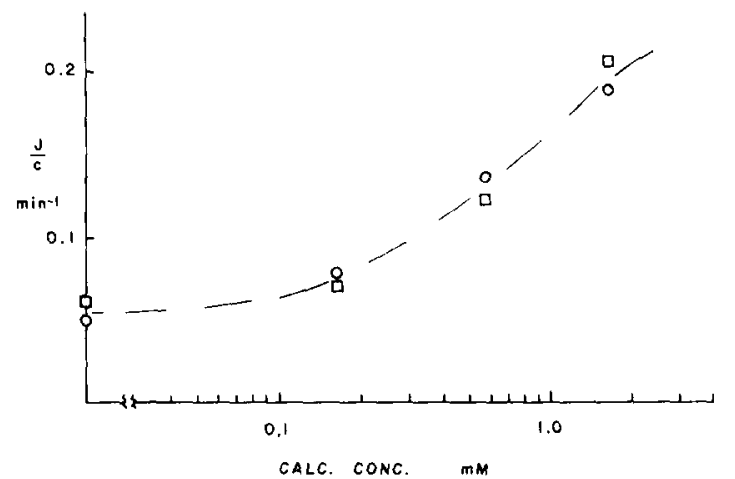

Fig. 5. Concentration dependence of activation effect of ADP and ATP in hemolyzed-resealed cells. Cells were incubated with A23187 at $0.01 \mathrm{mg} / \mathrm{ml}$ for $1 \mathrm{~h}$, hemolyzed and resealed at the concentration of ADP or ATP shown. O-.... O ATP, [ ADP. Bank blood 31 days old when ATP was run. 50 days old when ADP was run. the activation by resealing with ATP or ADP is obtained with red cells from old bank blood, i.e. the DMSO controls, as well as with cells further depleted by incubation with A23187 or with iodoacetamide plus inosine. For the higher concentrations of ATP and ADP the flux coefficients come close to those for red cells from freshly drawn blood.

To check that the results with the resealed cells were due to an effect on the inside of the membrane the following experiments were done. Incubation of intact erythrocytes with ATP or ADP at $2.5 \mathrm{mM}$ had no effect on glucose transport. Resealing without ADP, then washing the cells and incubating with ADP had no effect. Furthermore resealing without ADP followed by incuba- 


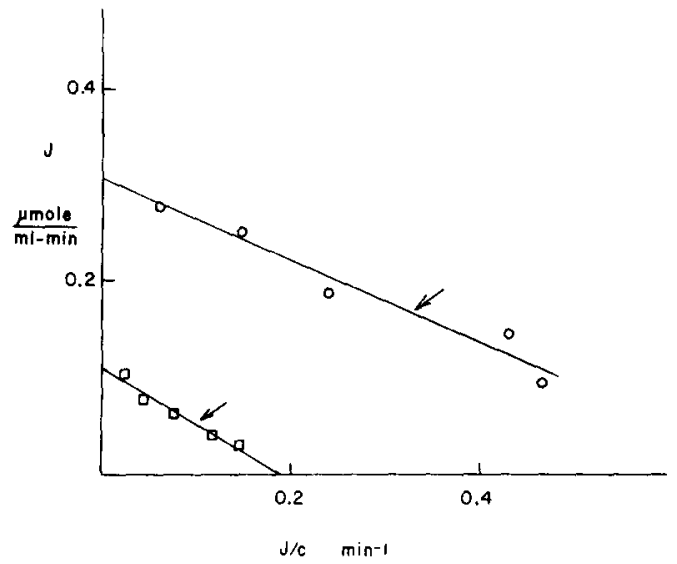

Fig. 6. Hofstee plot from a study of dependence of flux on glucose concentration. Cells from 34-day-stored bank blood incubated with $0.01 \mathrm{mg} / \mathrm{ml} \mathrm{A23187}$ for $1.5 \mathrm{~h}$. The suspension was split and one half resealed without ADP or ATP $(\square-\square)$, the other half was resealed with ADP at $2.4 \mathrm{mM}$ $(\mathrm{O}-\mathrm{O})$. Arrows indicate point on each line corresponding to $c=0.5$.

tion in ADP containing reseal medium from cells that showed the activation effect, had no effect on glucose transport. Also, cells could be hemolyzed and resealed with medium containing no ATP or
ADP, then washed and again hemolyzed and resealed with ATP or ADP to give the typical effect.

Fig. 5 shows the dependence of the activation effect on concentration of ADP and ATP run on the same sample of blood but 19 days apart; the experiment with ATP was run first. In other experiments the upper plateau came at 3-4 $\mathrm{mM}$. Fig. 6 shows a Hofstee plot from A23187-treated cells resealed with ADP at $2.4 \mathrm{mM}$ or with medium containing no ADP. Again the activation effect is an increase in $J_{\mathrm{m}}$. The arrows in Fig. 6 show the points on the curves corresponding to $c=0.5$. Note that for the cells resealed without ADP the flux coefficient is $0.1 \mathrm{~min}^{-1}$ whereas for the ADP loaded cells it is about $0.33 \mathrm{~min}^{-1}$, at $c=0.5$. Direct fit of the Hofstee plot gave $J_{\mathrm{m}}=0.30, K_{\mathrm{m}}=$ 0.41 for the ADP loaded cells and $J_{\mathrm{m}}=0.109$, $K_{\mathrm{m}}=0.57$ for the cells not loaded. Fitting the Michaelis-Menten equation by weighted nonlinear least squares gave $J_{\mathrm{m}}=0.30, K_{\mathrm{m}}=0.42$ and $J_{\mathrm{n}}=$ $0.11, K_{\mathrm{m}}=0.58$ for the two sets. Note that the scale in Fig. 6 is different from that in Fig. 4; the data for the A23187-treated red cells in Fig. 4 and those for resealed A23187-treated cells in Fig. 6 are quite close together.

TABLE IV

RECOVERIES OF ADENINE NUCLEOTIDES AFTER RESEALING GHOSTS WITH ADP OR ATP

\begin{tabular}{|c|c|c|c|c|c|c|c|}
\hline \multirow[t]{2}{*}{ Expt. } & \multirow{2}{*}{$\begin{array}{l}\text { Material } \\
\text { loaded }\end{array}$} & \multirow{2}{*}{$\begin{array}{l}\text { Concn. } \\
(\mathrm{mM})\end{array}$} & \multirow{2}{*}{$\begin{array}{l}\text { Other } \\
\text { conditions }\end{array}$} & \multirow{2}{*}{$\begin{array}{l}\text { Total } \\
\text { recovery } \\
(\%)\end{array}$} & \multicolumn{3}{|c|}{ Percent of amount recovered } \\
\hline & & & & & ATP & ADP & AMP \\
\hline \multirow[t]{2}{*}{$2 / 8$} & ADP & $\begin{array}{l}2.00 \\
2.00\end{array}$ & $\begin{array}{l}{\left[\mathrm{Ca}^{2+}\right]=0} \\
{\left[\mathrm{Ca}^{2+}\right]=7 \mathrm{pM}}\end{array}$ & $\begin{array}{l}27.3 \\
34.7\end{array}$ & $\begin{array}{l}88.3 \\
81.2\end{array}$ & $\begin{array}{l}11.7 \\
14.6\end{array}$ & $\overrightarrow{4} .2$ \\
\hline & ATP & $\begin{array}{l}1.99 \\
1.99\end{array}$ & $\begin{array}{l}{\left[\mathrm{Ca}^{2+}\right]=0} \\
{\left[\mathrm{Ca}^{2+}\right]=7 \mathrm{pM}}\end{array}$ & $\begin{array}{l}35.9 \\
46.6\end{array}$ & $\begin{array}{l}78.9 \\
81.5\end{array}$ & $\begin{array}{l}20.7 \\
18.5\end{array}$ & $\begin{array}{l}0.4 \\
-\end{array}$ \\
\hline \multirow[t]{2}{*}{$2 / 23$} & ADP & $\begin{array}{l}2.48 \\
2.48\end{array}$ & ouabain $^{a}$ & $\begin{array}{l}51.5 \\
52.0\end{array}$ & $\begin{array}{l}79.5 \\
77.3\end{array}$ & $\begin{array}{l}18.1 \\
17.4\end{array}$ & $\begin{array}{l}2.4 \\
5.3\end{array}$ \\
\hline & ATP & $\begin{array}{l}2.48 \\
2.48\end{array}$ & $\begin{array}{l}\text { ouabain } \\
\text { o }^{-}\end{array}$ & $\begin{array}{l}56.8 \\
61.5\end{array}$ & $\begin{array}{l}84.7 \\
80.0\end{array}$ & $\begin{array}{l}13.1 \\
16.7\end{array}$ & $\begin{array}{l}2.2 \\
3.2\end{array}$ \\
\hline \multirow[t]{2}{*}{$3 / 12$} & ADP & $\begin{array}{l}2.40 \\
2.40\end{array}$ & Double reseal & $\begin{array}{l}43.7 \\
26.6\end{array}$ & $\begin{array}{l}85.9 \\
87.7\end{array}$ & $\begin{array}{l}11.8 \\
10.9\end{array}$ & $\begin{array}{l}2.3 \\
1.4\end{array}$ \\
\hline & ATP & $\begin{array}{l}2.41 \\
2.41\end{array}$ & Double reseal ${ }^{b}$ & 50.6 & 90.2 & 9.8 & - \\
\hline
\end{tabular}

\footnotetext{
a $0.16 \mathrm{mM}$ in reseal solution.

b Sample lost.
} 


\section{Chromatography of extracts from resealed cells}

In three experiments the cells were washed after the reseal, alcoholic extracts were prepared and paper chromatograms were run in ammonia-isobutyric acid following the method given by Smith [19]. The spots for AMP, ADP and ATP were cut out, eluted and absorbance was measured at 259 $\mathrm{nm}$ with a Beckman B spectrophotometer. Table IV gives the recoveries after resealing with ADP or ATP. The total recovery is the least reliable because it depends on an estimate of intracellular water in the pellet of resealed cells which could be in error by $20 \%$. The important points to note are that within each experiment total recovery is higher for ATP loading than for ADP loading and that $80-90 \%$ of the recovered adenine nucleotides is ATP whether ADP or ATP are loaded. The latter is not unexpected since red blood cells are known to have high levels of adenylate kinase and although it is a soluble enzyme significant amounts are bound to ghosts at low ionic strength [20]. Human red blood cells also have significant levels of AMP deaminase, adenosine deaminase, purine nucleoside phosphorylase and adenine phosphoribosyltransferase. Note that very little AMP was found in the extracts; removal of AMP would tend to drive the adenylate kinase reaction to convert all of the ADP into ATP.

TABLE V

RESULTS OF DOUBLE RESEAL STUDIES

\begin{tabular}{|c|c|c|c|c|}
\hline \multirow[t]{2}{*}{ Expt. } & \multirow{2}{*}{$\begin{array}{l}\text { Com- } \\
\text { pound }^{\text {a }}\end{array}$} & \multicolumn{2}{|c|}{ Compound present } & \multirow{2}{*}{$\begin{array}{l}J / c \\
\left(\min ^{-1}\right)\end{array}$} \\
\hline & & $\begin{array}{l}\text { Reseal } \\
1\end{array}$ & $\begin{array}{l}\text { Reseal } \\
2\end{array}$ & \\
\hline \multirow[t]{5}{*}{$3 / 25$} & - & - & - & 0.041 \\
\hline & $\mathrm{ADP}$ & + & + & 0.177 \\
\hline & $\mathrm{ADP}$ & + & 0 & 0.069 \\
\hline & ATP & + & + & 0.225 \\
\hline & ATP & + & 0 & 0.087 \\
\hline \multirow[t]{3}{*}{$4 / 29$} & - & - & - & 0.093 \\
\hline & ATP & 0 & + & 0.303 \\
\hline & ATP & + & 0 & $0.115,0.149$ \\
\hline \multirow[t]{3}{*}{$6 / 15$} & - & - & - & 0.093 \\
\hline & ATP & + & + & $0.295,0.311$ \\
\hline & ATP & + & 0 & $0.154,0.163$ \\
\hline
\end{tabular}

${ }^{a}$ Present at $2.01 \mathrm{mM}$ at start of reseal.

\section{Decay of activation}

It was found that red cells could be subjected to two successive cycles of hemolysis and resealing and the typical activation given by ATP or ADP was obtained if the nucleotides were present in only the second reseal. For cells resealed with ATP and then resealed without ATP, although the second reseal should have reduced ATP levels by a factor of 25-30, enough to put it at the bottom of the activation concentration dependence curve, Fig. 5, a small activation, 20-25\%, remained. Although the effect was small it appeared consistently in three experiments, shown in Table V. Part of these results are also given in Table III.

\section{Photolytic labeling}

A suspension of the erythrocytes, treated with A23187, was split into two equal parts; one was resealed with ATP at $2 \mathrm{mM}$, the other was resealed without ATP in the hemolysis-reseal medium. Both preparations were subjected to ultraviolet photolytic labeling with tritiated cytochalasin $\mathrm{B}[21,22]$. The method of Carter-Su et al. [21] was used and the photolytic exposures were done in her laboratory. Each preparation was split in two; One was incubated with sorbitol the other with D-glucose at $527 \mathrm{mM}$ before addition of the tritiated cytochalasin B. After exposure to the ultraviolet the ghost cells were washed, dissolved in SDS and run by polyacrylamide gel electrophoresis. The gels were fixed and stained with Coomassie blue and sliced into $2.7 \mathrm{~mm}$ slices for counting. The results are shown in Fig. 7. The shift in baseline with different degrees of labeling has been seen by others (Carter-Su, C., personal communication). The first labeling peak in slices 4,5 , and 6 falls right on bands 1 and 2; most of band 3 falls in slices 12 and 13. The glucose transporter should fall in the slices between bands 3 and 5 [2,3], slices 14-20.

To calculate labeling in slices $4-6$ the average of the counts in slices $2,7,8$ and 9 was taken as background. For slices 14-20, the average of the counts in slices 21-27 was taken as background labeling. There is considerable differential labeling of the ghosts resealed with ATP, Fig. $7 b$, and much less for those resealed without ATP, Fig. 7a. Table VI summarizes the counts above background in bands 1 and 2 and in slices 14-20. 

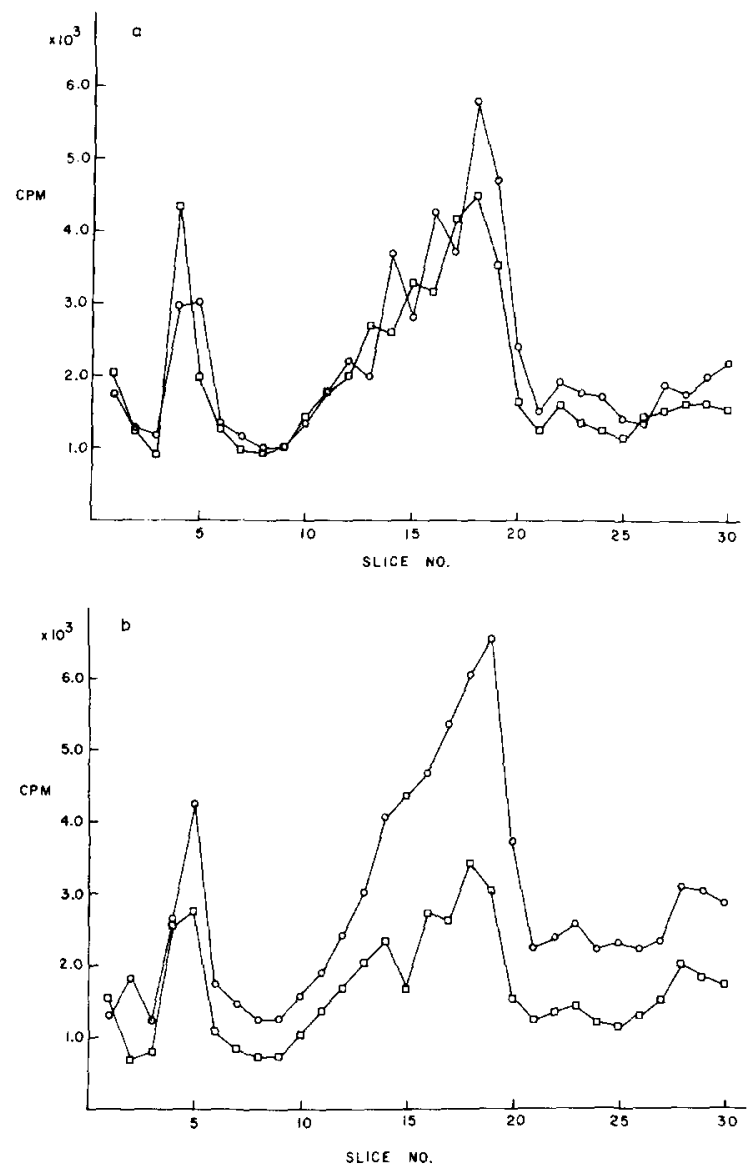

Table VI also gives the counts in 14-20 after adjustment to the same total counts in slices 4,5 , and 6 . Note that the labeling in slices $14-20$ is about the same in ATP-loaded and control cells; this is striking in the counts adjusted to equal labeling in slices 4-6. The differential labeling, $\mathrm{Ia}-\mathrm{Ib}$ and IIa - IIb, is greater in the ATP-treated ghosts because of a greater inhibition of labeling by glucose.

The experiment shown in Fig. 7 and summarized in Table VI was run twice but extensive polymerization occurred in one run so that all Coomassie blue staining was restricted to the first $\mathrm{cm}$ of the gels. Nonetheless calculation of the ratio of differential labeling for total counts in the first $\mathrm{cm}$ gave a value of 1.7 for $(\mathrm{IIa}-\mathrm{IIb}) /(\mathrm{Ia}-\mathrm{Ib})$.

Fig. 7. Photolytic labeling with tritiated cytochalasin B. Cells were subjected to two hemolysis and reseal cycles. One half of the preparation was resealed without ATP (Fig. 7a), the other half was resealed with ATP at $2 \mathrm{mM}$ (Fig. 7b). Each preparation was split; sorbitol was added to one half $(\mathrm{O}-\mathrm{O})$, D-glucose to the other ( $\square-\square$ - $\square$. Tritiated cytochalasin B was added and after $15 \mathrm{~min}$ incubation in the dark, all preparations were exposed to ultraviolet from a mercury arc lamp. The ordinate gives the cpm in $2.7 \mathrm{~mm}$ slices from the $5 \%$ polyacrylamide gels.

TABLE VI

PHOTOLYTIC LABELING

\begin{tabular}{|c|c|c|c|c|c|}
\hline & \multirow[t]{2}{*}{$\begin{array}{l}\text { Reseal } \\
\text { condition }\end{array}$} & \multirow{2}{*}{$\begin{array}{l}\text { D-Glucose } \\
\text { present } \\
\text { during } \\
\text { photolysis }\end{array}$} & \multicolumn{2}{|c|}{$\begin{array}{l}\text { Total counts } \\
\text { above background }\end{array}$} & \multirow{2}{*}{ 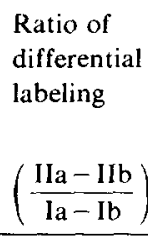 } \\
\hline & & & $\begin{array}{l}\text { Slices } \\
4-6^{a}\end{array}$ & $\begin{array}{l}\text { Slices } \\
14-20^{b}\end{array}$ & \\
\hline Ia & No ATP & 0 & 4063 & 15928 & \multirow{4}{*}{4.2} \\
\hline Ib & No ATP & + & 4751 & 13480 & \\
\hline IIa & ATP & 0 & 4801 & 18583 & \\
\hline IIb & ATP & + & 4057 & 8265 & \\
\hline \multicolumn{6}{|c|}{ Adjusted to $4500 \mathrm{cpm}$ in slices $4,5,6$} \\
\hline Ia & & & 4500 & 17643 & \multirow{4}{*}{1.7} \\
\hline Ib & & & 4500 & 12769 & \\
\hline IIa & & & 4500 & 17420 & \\
\hline IIb & & & 4500 & 9167 & \\
\hline
\end{tabular}

Bands 1 and 2; background was taken as average of slices 2, 7,8 and 9 .

b Background taken as average of slices 21-27. 


\section{Discussion}

Before discussing the implications of these findings for glucose transport and regulation, I should like to integrate the different observations.

The activation of glucose transport by $A T P$ and $A D P$

I have found that the zero-trans initial influx of glucose in human erythrocytes depleted by long storage, by incubation with A23187 in presence of calcium, or by incubation with iodoacetamide and inosine is decreased to levels $20-30 \%$ of those found in red cells from freshly drawn blood. Loading the cells with ATP or ADP at concentrations of 2-3 mM reverses the inhibition; the peak reversal occurs at concentrations in the normal range for ATP. The activation by ATP is reversible. The effect involves a change in transport capacity, $J_{m}$, not in the $K_{\mathrm{m}}$ of the system. The studies with the photolytic labeling technique show a much greater glucose sensitive labeling in the ATP loaded cells, a finding consistent with the change in $J_{\mathrm{m}}$. Interestingly the photolytic labeling was approximately the same in depleted cells resealed with or without ATP. This implies that the cytochalasin B binds to active and inactive transporters but that glucose displaces cytochalasin $\mathrm{B}$ only from the active transporters. This is right in line with the finding that although there is a marked loss in the transport activity of the carrier proteins during purification, cytochalasin $\mathrm{B}$ binding is not lost [23].

\section{Are $A T P$ and ADP both active?}

The chromatographic studies on extracts of the resealed cells show that most of the ADP disappears; after the resealing-incubation ATP makes up $80 \%$ of the recovered nucleotides and less than $50 \%$ was recovered in most of the loadings with ADP. These results are not unexpected. Human red cells have high levels of adenylate kinase. So if the AMP formed is removed, as indicated by the chromatographic results, the effect would be to drive this reaction so as to deplete the ADP. These results suggest that ATP is the source of the activation but do not rule out some effect from ADP. In those studies in which ADP and ATP were tested at the same concentrations the ATP effect was usually a little larger than that due to
ADP. It is difficult to say whether that is consistent with the differences in chromatographic recoveries. However, in normal red blood cells ADP levels are kept quite low so in intact erythrocytes ATP must be the source of the activation.

\section{What is the mechanism of the activation?}

It is clear that the activation of glucose transport is a reversible activation of membrane transport proteins. An idea such as the recruitment hypothesis will not do here. There is no intracellular membrane pool. Furthermore, the results of the hemolysis-reseal experiments rule out a recruitment of soluble molecules from the cytoplasm because there is a 25-30-fold dilution of the intracellular phase with each hemolysis-reseal but the same effect is obtained with two hemolysis-reseals as with one, so long as ATP is present in the last resealing incubation. The finding that there is a residual effect when ATP is washed out in a second hemolysis-reseal suggests there is a membrane alteration which turns over fairly rapidly, i.e. about $75 \%$ during the 1 -h reseal-incubation. A phosphorylation of membrane protein is an obvious candidate and will be the subject of a separate study. On the other hand we have to keep in mind the possibility of some heterogeneity in the hemolysis and reseal of the cells as a possible alternative explanation.

\section{Is the activation specific for glucose transport?}

Is the activation of glucose transport specific for the glucose transport system or is it possibly a more general membrane effect? Two preliminary experiments have been run to see if resealing depleted cells with 3.2 and $4.0 \mathrm{mM}$ ADP activated the facilitated diffusion of $\mathrm{L}$-leucine. In one experiment a 1.7 -fold increase occurred, in the other a 1.15-fold increase. Lucas-Heron and Fontenaille [24] have reported that urate uptake in human red cells resealed with ATP (concentration not given) was 1.75 -fold greater than in cells resealed without ATP. Thus we have evidence for a more widespread membrane effect which warrants further investigation.

Implications for the mechanism of glucose transport The glucose facilitated diffusion system in hu- 
man red cells was the first such system studied and it was for this system that the first simple carrier models were proposed. But as the results accumulated it became more and more difficult to reconcile all of the experimental findings with the simple symmetric carrier model. In response, first asymmetric models were proposed and then a number of multiple carrier and non-carrier models. Details may be found in reviews by LeFevre [ 2 ], Eilem and Stein [25] and Widdas [26]. But the experimental work and the theories were developed in a fixed context, the belief that the glucose transport system in red cells was of fixed, constant capacity. With the results I report here it is clear that the system activity changes when intracellular ATP levels change. Some of the evidence for asymmetry and for multiple systems depended on comparing kinetics of zero-trans influx, infinite-cis efflux and equilibrium exchange. Might not ATP levels have changed in the experiments that involved loading with glucose? The interpretation of some of the experiments will have to be reevaluated in light of the findings that the glucose facilitated diffusion system is regulated by ATP levels.

\section{Conclusion}

I have presented evidence that facilitated diffusion of glucose in human red cells is regulated by ATP levels. Not only is this significant for understanding the glucose transport system in these cells but it provides another example of regulation of a membrane transport system, a regulation in a cell which is so easy to use that it has served as a prototype for the study of transport and other membrane properties.

\section{Acknowledgements}

I wish to thank Michael Markowitz and John Koch for their able and willing technical assistance. I am especially grateful to Dr. Christin Carter-Su for her advice and help in doing the photolytic labeling experiments. This work was supported in part by grant GM24507 from NIH, DHEW.

\section{References}

1 Czech, M.P. (1980) Diabetes 29, 399-409

2 LeFevre, P.G. (1975) Curr. Top. Membranes Transp. 7, 109-215

3 Barnett, J.E.G., Holman, G.D., Chalkley, R.A. and Munday, K.A. (1975) Biochem. J. 145, 417-429

4 Eilam, Y. (1975) Biochim. Biophys. Acta 401, 364-369

5 Ginsburg, H. (1978) Biochim. Biophys. Acta 506, 119-135

6 Elbrink, J. and Bihler, I. (1975) Science 188, 1177-1184

7 Jacquez, J.A. (1982) Fed. Proc. 41, 1414

8 Batt, E.R. and Schachter, D. (1973) J. Clin. Invest. 52, 1686-1697

9 Ferreira, H.G. and Lew, V.L. (1977) in Membrane Transport in Red Cells (Ellory, J.C. and Lew, V.L., eds.), pp. 53-100, Academic Press, New York

10 Karlish, S.J.D., Lieb, W.R., Ram, D. and Stein, W.D. (1972) Biochim. Biophys. Acta 255, 126-132

11 Schwoch, G. and Passow, H. (1973) Mol. Cell. Biochem. 2. 197-218

12 Johnson, R.M. (1975) J. Membrane Biol. 22, 231-253

13 Johnson, R.M. and Kirkwood, D.H. (1978) Biochim. Biophys. Acta 509, 58-66

14 Coté, C. and Jacquez, J.A, (1979) Biochim. Biophys. Acta $557,112-121$

15 Martell, A.E. and Smith, R.M. (1974) in Critical Stability Constants, Vol. 1, Plenum Press, New York

16 Sillen, L.G. and Martell, A.E. (1971) in Stability Constants of Metal-Ion Complexes. The Chemical Society, London. Spec. Publ. No. 25

17 Perrin, D.D. (1979) in Constants of Metal-Ion Complexes. 2nd Edn., IUPAC Chem. Data Ser. No. 22, Pergamon Press, Oxford

18 Brewer, G.J. (1974) in The Red Blood Cell (Surgenor, D., ed.), Vol. 1, pp. 473-508, Academic Press, New York

19 Smith, I. (1969) Chromatographic and Electrophoretic Techniques, Vol. I, Chromatography, 3rd Edn., Ch. 12, W. Heinemann Medical Books Ltd, London

20 Tsuboi, K.K. (1978) in Methods in Enzymology, Vol. 51 (Hoffe, P.A. and Jones, M.E.. eds.), pp. 467-473, Academic Press, New York

21 Carter-Su, C.. Pessin. J.E. and Czech. M.P. (1982) Fed. Proc. 41, 1415

22 Shanahan, M.F. (1982) Fed. Proc. 41. 1414

23 Baldwin, S.A. and Lienhard, G.E. (1981) Trends Biochem. Sci. 6, 208-211

24 Lucas-Heron, B. and Fontenaille, C. (1979) Biochim. Biophys. Acta 553, 284-294

25 Eilam, Y. and Stein, W.D. (1974) in Methods in Membrane Biology (Korn, E.D.. ed.), Vol. 2, pp. 283-354. Plenum Press, New York

26 Widdas, W.F. (1980) in Current Topics in Membranes and Transport (Bronner, F. and Kleinzeller, A., eds.), Vol. 14 pp. 165-223, Academic Press, New York 